\title{
Long term Fluoride Release of Newly Developed Alkasite Based Restorative Material
}

\author{
Edibe Egil ${ }^{1 *}$ \\ ${ }^{1}$ İstanbul Gelişim Üniversitesi Diş Hekimliği Fakültesi Pedodonti Ana Bilim Dalı,İstanbul, Turkey
}

Geliş / Received: 25/10/2020, Kabul / Accepted: 11/12/2020

\begin{abstract}
Glass ionomer cement in dentistry prevents demineralization process through its fluoride release property and is effective in the induction of remineralization phase. Being low of flexural strength of glass ionomer has caused the search for different materials that can release fluoride. In this study, fluoride release of new alkasite based filling material which has been developed as an alternative to glass ionomer cement has been evaluated. Three commercially available filling materials were tested for the present study: Traditional glass ionomer (Ketac Molar Easymix, 3M ESPE, Germany), resin modified glass ionomer (Nova Glass LC, Imicryl, Konya,Turkey) and Alkasite filling (Cention N, Ivoclar, Vivadent,Schaan, Liechtenstein). Fluoride release of three filling materials were measured at certain intervals for 63 days. Nova Glass LC, Ketac Molar easymix and Cention $\mathrm{N}$ released fluoride throughout the study. Fluoride releases of Nova Glass LC for the first 24 hours were significantly higher than Ketac Molar and Cention $\mathrm{N}$ group $(\mathrm{p}<0.05)$. It has been observed that Cention $\mathrm{N}$ can release fluoride in the long term just like Ketac Molar Easymix and Nova Glass LC glass ionomer cement.
\end{abstract}

Keywords: fluoride release, glass ionomer, alkasite filling, dental materials

\section{Yeni Geliştirerilen Alkasit Bazlı Restoratif Materyalin Uzun Dönem Fluor Salınımı}

\section{$\ddot{O} z$}

Diş hekimliğinde cam iyonomer simanlar fluor salınımı özelliği ile demineralizesyon sürecini engellemekte ve remineralizasyon fazının indüklenmesinde etkili olmaktadır. Cam iyonomerin bükülme direncinin düşük olması fluor salınımı yapabilen farklı malzeme arayışlarına neden olmuştur. Bu çalışmada cam iyonomer simanlara alternatif olarak geliştirilen yeni alkasite dolgu materyalinin fluor salınımı özelliği değerlendirilmiştir. Çalışmamızda ticari olarak satılan alkasit bazlı dolgu malzemesi (Cention N, Ivoclar, Vivadent, Schaan, Liechtenstein), geleneksel cam iyonomer siman (Ketac Molar Easymix, 3M ESPE, Germany) ve rezin bazlı cam iyonomer siman (Nova Glass LC, Imicryl, Konya, Turkey) test edilmiştir. 3 dolgu malzemesinin 63 gün boyunca fluor salınımı belli aralıklarla ölçülmüsştür. Nova Glass LC, Ketac Molar Easymix ve Cention $\mathrm{N}$ çalışmada incelenen süre boyunca fluor salınımı yapmıştır. İlk 24 saat Nova Glass LC'nin fluor salınımı Ketac Molar ve Cention N grubuna göre anlamlı derecede yüksek bulunmuştur $(\mathrm{p}<0,05)$. Cention N'in Ketac Molar Easymix ve Nova Glass LC cam iyonomer siman gibi uzun dönem fluor salınımı yapabildiği gözlemlenmiştir.

Anahtar Kelimeler: fluor salınımı, cam iyonomer, alkasit dolgu, dental materyaller 


\section{Introduction}

Fluoride is commonly used to contribute the remineralization of dentin and enamel that are exposed to acid threat in oral environment and to stop and limit active dental caries (Egil, 2020; Garcez, Buzalaf, \& De Araújo, 2007). Glass ionomers that are commonly used in dentistry prevent demineralization process by providing fluorapatite and fluorhydroxyapatite formation on the tooth surface through their fluoride release properties and they have an influence on the induction of remineralization phase (Bansal \& Bansal, 2015). It is possible through this property that reduction in the formation of secondary dental caries especially for individuals with high caries risks, and neutralization of low $\mathrm{pH}$ that causes demineralization can be achieved (Garcez et al., 2007). Dental caries can be prevented through fluoride release from the material to both saliva and to the dental plaque (Chen et al., 2012).

Traditional Glass ionomer cements were introduced in early 1970s (Wilson \& Kent, 1972). Traditional glass ionomer cements compose of reinforced filling particles that surround polymer matrixes cross linked to ions. Fluoroaluminosilicate composes the powder of traditional glass ionomer cements. There are high amounts of calcium, fluoride, aluminum and silica in the powder, and polyacrylic, tartaric and itaconic acid polymer and copolymers compose the liquid of it (Lohbauer, 2010).

Glas ionomers are advantageous because they can adhere to the structure of tooth, also since they can release fluoride, they have anti-cariogenic properties and being compatible thermally with the tooth enamel is among the advantages because they are coefficient of thermal expansion (Xie, Brantley, Culbertson, \& Wang, 2000). Resin modified glass ionomer cements were developed in the early 1990s in order to solve the problems of moisture sensitivity and low mechanical strength of glass ionomer cements. (Mitra, 1991; Sidhu, 2011) Resin based glass ionomers contain a monomer and initiator system unlike conventional glass ionomers.

Alkasite restorative material that has been developed as an alternative to glass ionomers recently has been introduced to the market. Alkasite refers to a new category of filling material, which releases fluoride, calcium and hydroxide ions. Cention $\mathrm{N}$ is a filling material that belongs to alkasite material group with high flexural strength. These alkasite fillers enable the regulation of $\mathrm{pH}$ levels by releasing hydroxide ions during acid attack. As a result of this, they contribute to prevention of demineralization and the remineralization of enamel through the release of high amounts of fluoride and calcium ions (Todd, 2016).

This study aims to compare the fluoride release of alkasite filling Cention $\mathrm{N}$ and 2 established brands of glass ionomer: resin modified glass ionomer Nova Glass LC and traditional glass ionomer Ketac Molar Easymix. The null hypothesis is that there is no difference between alkasite filling, conventional and resin-modified glass ionomers with respect to the fluoride release. 


\section{Material and Methods}

\subsection{Disc preparation}

Three commercially available filling materials were tested for the present study: Traditional glass ionomer (Ketac Molar Easymix, 3M ESPE, Germany), resin modified glass ionomer (Nova Glass LC, Imicryl, Konya, Turkey) and alkasite filling (Cention N, Ivoclar, Vivadent, Schaan, Liechtenstein). The composition of tested materials was given in Table 1. A total of 30 samples, ten disc-shaped samples for each material (5 $\mathrm{mmm}$ diameter and $2 \mathrm{~mm}$ thickness) were prepared by using a polytetrafluoroethylene mold and glass slides were placed on both sides of the mold. Lightcured glass ionomer discs were photopolymerized by using a led unit (Elipar, 3M ESPE, MN, USA) for 40 seconds with an output irradiance of $1200 \mathrm{~mW} / \mathrm{cm} 2$ and wavelength range of $430-480 \mathrm{~nm}$. A calibrated radiometer system (Hilux Radiometer, Curing Radiometer, Benlioglu, Ankara, Turkey) was employed to confirm the irradiance at each use.

Table 1: Composition of tested materials

\begin{tabular}{|c|c|c|c|c|c|}
\hline & & \multicolumn{2}{|c|}{ composition } & \multirow[t]{2}{*}{ manufacturer } & \multirow[t]{2}{*}{ LOT } \\
\hline & & powder & liquid & & \\
\hline $\begin{array}{l}\text { Glass } \\
\text { ionomer }\end{array}$ & $\begin{array}{l}\text { Ketac Molar } \\
\text { Easymix }\end{array}$ & $\begin{array}{l}\text { fluorosilicate glass, Al- } \\
\text { Ca-La copolymer }\end{array}$ & $\begin{array}{l}\text { Polyalquenoic acid, } \\
\text { tartaric acid, water }\end{array}$ & $\begin{array}{c}3 \mathrm{M} \\
\text { ESPE,Germany }\end{array}$ & 3960620 \\
\hline $\begin{array}{l}\text { Resin } \\
\text { modified } \\
\text { glass } \\
\text { ionomer }\end{array}$ & $\begin{array}{c}\text { Nova Glass- } \\
\text { LC }\end{array}$ & $\begin{array}{l}\text { Fluoroaluminosilicate } \\
\text { glass, pigments, }\end{array}$ & $\begin{array}{c}\text { dimethacrylates, } \\
\text { HEMA,initiators, } \\
\text { stabilizer }\end{array}$ & $\begin{array}{c}\text { Imicryl, } \\
\text { Konya,Turkey }\end{array}$ & 9051 \\
\hline $\begin{array}{l}\text { Alkasite } \\
\text { filling }\end{array}$ & Cention N & $\begin{array}{l}\text { Calcium fluoro-silicate } \\
\text { glass, barium glass, } \\
\text { calcium-barium- } \\
\text { aliminium fluoro- } \\
\text { silicate glassiso-fillers, } \\
\text { ytterbium trifluoride, } \\
\text { initiators, pigments, }\end{array}$ & $\begin{array}{l}\text { dimethacrylates, } \\
\text { initiators, stabilizer }\end{array}$ & $\begin{array}{c}\text { Ivoclar } \\
\text { Vivadent, } \\
\text { Schaan, } \\
\text { Liechtenstein }\end{array}$ & W96066 \\
\hline
\end{tabular}

The powder: liquid ratio was prepared as being instructed by the manufacturer. Then mixing restorative materials was placed inside the mold and polyester strips (Mylar strips) were placed with glass slabs below and above the paste filled mold. Polymerized samples were taken out from the mold softly and the excessive material was discharged through a sharp blade and they were stored for 24 hours at $37{ }^{\circ} \mathrm{C}$ deionized water before testing.

\subsection{Fluoride release rate measurements}

Each sample was immersed in $5 \mathrm{ml}$ deionized water in a plastic cup, and stored at $37 \pm 0.5{ }^{0} \mathrm{C}$ during study period. The first fluoride ion release measured at 24 hours. After the samples were removed from the storage container and rinsed with deionized water, they were placed in a new container filled with $5 \mathrm{ml}$ of deionized water every day. The amount of fluoride release of the 
samples in the storage container was made with Thermo Orion $720 \mathrm{~A}+$ ionometer with the fluoride electrode (Orion-9609BN). Before each measurement, the electrode handpiece filled with a special filling solution (Orion ion plus filling solution 900061). Solutions were prepared at four different concentrations for calibration using $0.1 \mathrm{M} \mathrm{F}$ standard (100ppm, $10 \mathrm{ppm}, 1 \mathrm{ppm}$, $0.1 \mathrm{ppm})$. The Electrode was calibrated before measurement and accuracy of calibration was checked in every ten measurements. Between measurements, the electrode handpiece was rinsed with distilled water.

\subsection{Statistical analysis}

The statistical analysis was performed using IBM SPSS (SPSS Inc., V20, Chicago, IL, USA) program. Descriptive statistics were presented using mean and standard deviation. In order to compare fluoride release among groups significance by one-way analysis of variance (ANOVA) test was used. Tukey multiple comparison test was used for post hoc pairwise.
Statistical significance was accepted at a significance level of $\mathrm{P}<0.05$.

\section{Resarch Findings}

Fluoride releases of the materials tested in the study were shown in Table 2 and Figure 1. When the difference among materials used in the study was analyzed in terms of fluoride release, it was observed that there was a statistical significance on the 1st, 28th and 56th days. As a result of performed post hoc analysis, there was not a statistical significant difference between Nova Glass LC(NG) and Ketac Molar Easymix (KM). A significant difference between Cention $\mathrm{N}(\mathrm{CN})$ and $\mathrm{NG}$ was observed on the 1st day, it was observed that the amount of released fluoride from $\mathrm{CN}$ was lower than NG. There was a statistically significant difference between $\mathrm{CN}$ and $\mathrm{KM}$ on the 28th and 56th days. It was observed that amount of fluoride release from $\mathrm{CN}$ filling was higher than the amount of fluoride release from KM.

Table 2: Mean fluoride release of tested materials

\begin{tabular}{|c|c|c|c|c|}
\hline Day/group & $\begin{array}{c}\text { Nova Glass LC } \\
(\text { Mean } \pm \text { SD })\end{array}$ & $\begin{array}{c}\text { Ketac Molar Easymix } \\
(\text { Mean } \pm \text { SD })\end{array}$ & $\begin{array}{c}\text { Cention N } \\
(\text { Mean } \pm \text { SD })\end{array}$ & $\mathrm{p}$ \\
\hline 1 & $13.50 \pm 1.80^{\mathrm{a}}$ & $8.26 \pm 3.08^{\mathrm{a}, \mathrm{b}}$ & $3.90 \pm 1.35^{\mathrm{b}}$ & $\mathbf{0 . 0 0 5}^{*}$ \\
\hline 2 & $10.87 \pm 8.70$ & $2.99 \pm 0.73$ & $2.88 \pm 1.44$ & 0.170 \\
\hline 3 & $7.66 \pm 6.93$ & $2.08 \pm 0.28$ & $3.17 \pm 1.86$ & 0.295 \\
\hline 14 & $2.77 \pm 0.42$ & $0.83 \pm 013$ & $4.62 \pm 2.48$ & 0.051 \\
\hline 21 & $1.61 \pm 0.79$ & $0.51 \pm 0.06$ & $1.96 \pm 0.89$ & 0.094 \\
\hline 28 & $1.045 \pm 0.25^{\mathrm{a}, \mathrm{b}}$ & $0.41 \pm 0.04^{\mathrm{a}}$ & $1.19 \pm 0.41^{\mathrm{b}}$ & $\mathbf{0 . 0 3 0}^{*}$ \\
\hline 35 & $1.05 \pm 0.36$ & $0.79 \pm 0.61$ & $1.82 \pm 0.52$ & 0.106 \\
\hline 42 & $1.15 \pm 0.35$ & $0.82 \pm 0.23$ & $1.48 \pm 0.12$ & 0.052 \\
\hline 49 & $1.15 \pm 0.76$ & $0.69 \pm 0.28$ & $0.69 \pm 0.28$ & 0.139 \\
\hline 56 & $1.07 \pm 0.23^{\mathrm{a}, \mathrm{b}}$ & $0.51 \pm 0.09^{\mathrm{a}}$ & $1.03 \pm 0.08^{\mathrm{b}}$ & $\mathbf{0 . 0 0 8}^{*}$ \\
\hline 63 & $0.88 \pm 0.23$ & $0.31 \pm 0.06$ & $0.56 \pm 0.49$ & 0.165 \\
\hline
\end{tabular}


$\mathrm{P}^{*}$ one-way analysis of variance (ANOVA).

Same superscript letter within a column for each measurement day indicates no significant difference according to Tukey multiple comparison test $(\mathrm{P}>0.05)$

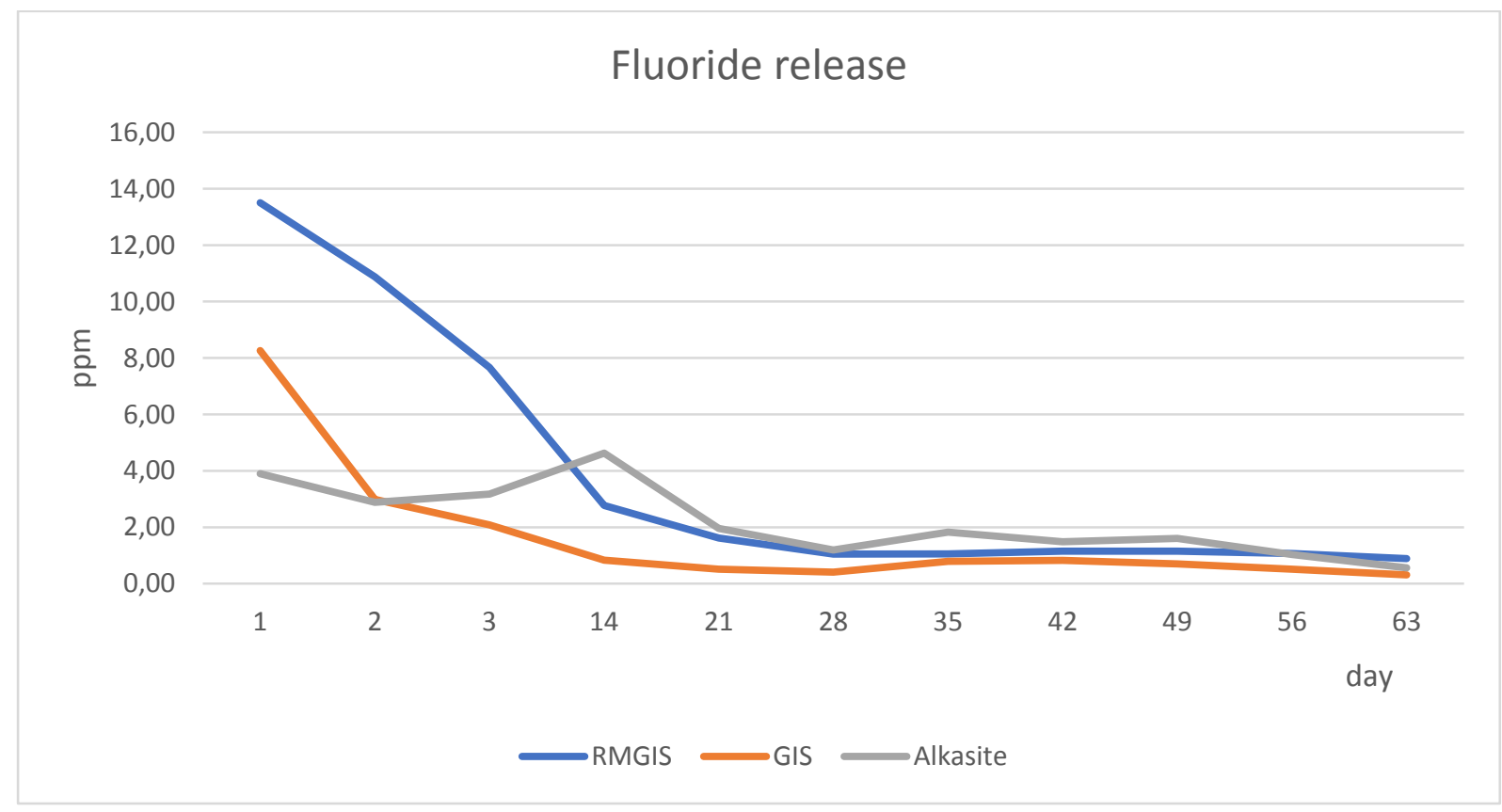

Figure 1: Fluoride release of tested materials

When the fluoride release of materials was monitored for 69 days, it was observed that the fluoride release decreases rapidly on the first 14 days. It was detected that the fluoride release of all tested materials continued over the span of 69 days.

\section{Results}

It is an important criterion while selecting materials for specific clinical practices that glass ionomers have fluoride release property. It has been accepted that traditional glass ionomers are effective for the prevention of dental caries formation through its long-term fluoride release properties. This study was conducted to evaluate recently introduced the fluoride release of bulk-fill restorative material $\mathrm{CN}$ at different time intervals and compare it to glass ionomer. To the best of our knowledge, long term fluoride release of $\mathrm{CN}$ has not been researched yet.

In this study, fluoride release of glass ionomer and alkasite based 3 filling materials was analyzed. In previous studies, it was reported that high fluoride release seen in the first 24 hours decreases rapidly after 24-72 hours, and approaches stable levels within 10-20 days (Khoroushi \& Keshani, 2013; P \& Kishore, 2005; Selimović-Dragaš et al., 2013; Sidhu, 2011; Wiegand, Buchalla, \& Attin, 2007). When the results were evaluated, the highest amount of fluoride release of $\mathrm{KM}$ and $\mathrm{NG}$ was observed in the first 24 hours, fluoride release continued decreasingly on the following days until the end of measurement period (until the day 63). Results supporting the literature were also obtained in our study. On the other hand, 
although there was a little decrease at the end of the first 24 hours for $\mathrm{CN}$ filling material, an increase in the amount of fluoride release was again observed on the 14th day, it was detected that there was a rapid decrease in the release after the 14th day and it reached a stable level.

When fluoride release of glass ionomer cements was evaluated among themselves, it was discovered that fluoride release of $\mathrm{NG}$ was higher than $\mathrm{KM}$ at each measurement time. Results supporting the findings of our study were reported in the previous studies (Kan, Messer, \& Messer, 1997; SelimovićDragaš et al., 2013).

The number of studies performed with $\mathrm{CN}$ is limited in literature. Gupta et al (2019), researched about the fluoride release of different glass ionomers and $\mathrm{CN}$ for 21 days. It was reported that glass ionomers released more fluoride than $\mathrm{CN}$ for all intervals of measurements. Panpisut et al (2020) compared resin modified glass ionomer with different contents and $\mathrm{CN}$ fluoride release, and they reported that cumulative fluoride release was at its highest in resin modified glass ionomer, then the second highest rate was in $\mathrm{CN}$. Although the results obtained from our study have similar results with the study of Gupta et al. for the first week, it was observed in the following days that the fluoride release of $\mathrm{CN}$ was higher than $\mathrm{KM}$ and NG. More studies are needed on this subject in the future.

This study has some limitations, fluoride release from a restorative material is affected by $\mathrm{pH}$, the mixing technique of material, powder-liquid ratio, and environmental conditions (Moreau \& Xu, 2010). In this study, fluoride release was analyzed by optimizing the conditions. Considering the changing oral environment, analysis of fluoride releases of materials under different circumstances is needed.

As a conclusion, fluoride release was detected from all materials tested in the study in all the test periods. The highest amount of fluoride release was observed in the first 24 hours. Fluoride release of $\mathrm{CN}$ was higher than KM and NG after the 14th day, till the end of day 56. Although the fluoride release of NG cement for the first 14 day was higher, $\mathrm{CN}$ can also release long term fluoride like $\mathrm{KM}$ and NG in the following days.

\section{References}

Bansal, R., \& Bansal, T. (2015). A comparative evaluation of the amount of fluoride release and re-release after recharging from aesthetic restorative materials: An in vitro study. Journal of Clinical and Diagnostic Research, 9(8), ZC11-ZC14.

https://doi.org/10.7860/JCDR/2015/11926.62 78

Chen, X., Du, M. Q., Fan, M. W., Mulder, J., Huysmans, M. C. D. N. J. M., \& Frencken, J. E. (2012). Caries-preventive effect of sealants produced with altered glass-ionomer materials, after 2 years. Dental Materials, 28(5), 554-560.

https://doi.org/10.1016/j.dental.2012.01.001.

Egil, E. (2020). Tuza, Süte Fluor Katılması ve Fluor Tabletleri. Türkiye Klinikleri Çocuk Diş Hekimliği - Özel Konular, 6(1), 7-10. Retrieved from

https://www.turkiyeklinikleri.com/article/trtuza-sute-fluor-katilmasi-ve-fluor-tabletleri89277.html

Garcez, R. M. V. D. B., Buzalaf, M. A. R., \& De Araújo, P. A. (2007). Fluoride release of six restorative materials in water and $\mathrm{pH}$ - 
cycling solutions. Journal of Applied Oral Science, 15(5), 406-411.

https://doi.org/10.1590/S1678-

77572007000500006

Gupta, N., Jaiswal, S., Nikhil, V., Gupta, S., Jha, P., \& Bansal, P. (2019). Comparison of fluoride ion release and alkalizing potential of a new bulk-fill alkasite. Journal of Conservative Dentistry, 22(3), 296.

https://doi.org/10.4103/jcd.jcd_74_19

Kan, K. C., Messer, L. B., \& Messer, H. H. (1997). Variability in cytotoxicity and fluoride release of resin-modified GlassIonomer Cements. Journal of Dental Research, 76(8), 1502-1507.

https://doi.org/10.1177/00220345970760081

301

Khoroushi, M., \& Keshani, F. (2013). A review of glass-ionomers: From conventional glass-ionomer to bioactive glass-ionomer. Dental Research Journal, 10(4), 411-420. Retrieved from

http://www.ncbi.nlm.nih.gov/pubmed/24130 573

Lohbauer, U. (2010). Dental glass ionomer cements as permanent filling materials? Properties, limitations and future trends. Materials, 3(1), 76-96.

https://doi.org/10.3390/ma3010076

Mitra, S. B. (1991). Adhesion to Dentin and Physical Properties of a Light-cured Glassionomer Liner/Base. Journal of Dental Research, 70(1), 72-74.

https://doi.org/10.1177/00220345910700011 201

Moreau, J. L., \& Xu, H. H. K. (2010). Fluoride releasing restorative materials: Effects of $\mathrm{pH}$ on mechanical properties and ion release. Dental Materials, 26(11). https://doi.org/10.1016/j.dental.2010.07.004
P, N. U., \& Kishore, G. (2005). Glass ionomer cement - The different generations. Trends in Biomaterials and Artificial Organs, 18(2), 158-165. Retrieved from https://manipal.pure.elsevier.com/en/publicat ions/glass-ionomer-cement-the-differentgenerations

Panpisut, P., \& Toneluck, A. (2020). Monomer conversion, dimensional stability, biaxial flexural strength, and fluoride release of resin-based restorative material containing alkaline fillers. Dental Materials Journal, 39(4), 608-615.

https://doi.org/10.4012/dmj.2019-020

Selimović-Dragaš, M., Hasić-Branković, L., Korać, F., Dapo, N., Huseinbegović, A., Kobašlija, S., ... Hatibović-Kofman, Š. (2013). In vitro fluoride release from a different kind of conventional and resin modified glass-ionomer cements. Bosnian Journal of Basic Medical Sciences, 13(3), 197-202.

https://doi.org/10.17305/bjbms.2013.2362

Sidhu, S. K. (2011). Glass-ionomer cement restorative materials: A sticky subject? Australian Dental Journal, 56(SUPPL. 1), 23-30. https://doi.org/10.1111/j.1834-7819. 2010.01293.x

Todd, J. (2016). Scientific Documantation: Cention N. Ivoclar Vivadent AG.

Wiegand, A., Buchalla, W., \& Attin, T. (2007, March 1). Review on fluoridereleasing restorative materials-Fluoride release and uptake characteristics, antibacterial activity and influence on caries formation. Dental Materials. Elsevier. https://doi.org/10.1016/j.dental.2006.01.022

Wilson, A. D., \& Kent, B. E. (1972). A new translucent cement for dentistry. The glass 
ionomer cement. British Dental Journal, 132(4), 133-135.

https://doi.org/10.1038/sj.bdj.4802810

Xie, D., Brantley, W. A., Culbertson, B. M., \& Wang, G. (2000). Mechanical properties and microstructures of glass-ionomer cements. Dental Materials, 16(2), 129-138. https://doi.org/10.1016/S01095641(99)00093-7. 